\title{
THE NATIONAL SECURITY IMPLIC TIONS OF HERDSMEN/FARMERS CONFLICTS IN KOGI STATE
}

\author{
B. A. Ojomah, S. P. Idakwoji, Y. P. Usman, F. O. Orokpo \\ DOI: 10.31364/SCIRJ/v7.i3.2019.P0319619 \\ http://dx.doi.org/10.31364/SCIRJ/v7.i3.2019.P0319619
}

\begin{abstract}
The conflicts between herdsmen and farmers in different parts of Nigeria are one of the major national discourse in recent times because of the security challenges that are involved. This study was carried out to identify the security implications of these conflicts on Kogi State and the nation at large and suggest possible way forward. Data were generated from primary and secondary sources via interviews and literature search derived from earlier research work by these same authors titled "Farmers/Herdsmen Crisis in Kogi State: Security and Developmental Implications". Analyses were qualitatively and quantitatively carried out. Findings reveal gross material, physical and psychological consequences of these conflicts, which suggest that the security implications are alarming. These combine with the existing national security issues facing Nigeria are signs that the country is drifting into a failed state. A policy formulation and implementation that recognizes the role of modernization and political economy to development and good governance are necessary antidotes to this drift.
\end{abstract}

Keywords: Conflicts, security, national security, modernization, political economy and failed state.

\section{INTRODUCTION}

From $1750 \mathrm{AD}$, it was observed that the Fulani, who migrated to Nigeria from Futa Jalon started competing for power with indigenous people of Northern Nigeria (Harnmonda, 1961). This backdrop, according to Makuberidze (2013, in Abraham, 2017) unarguably laid the foundation for conflicts between them (herdsmen) and farmers in Nigeria. The multifarious uses of land and its limitedness have necessitated that various shades of competition for its use must ensue. This has been centre of mankind conflicts since time immemorial (Rashid, 2012).

In Kogi State of Nigeria, there has been hue and cry by many people in various communities of the incessant herdsmen/farmers conflicts in the recent past. The conflicts have taken dangerous dimensions, to the extent that clashes have become frequent and culminating into killings, maiming, arson and invasion of communities. Local Government Areas with cases in recent times include Dekina, Igalamela/Odolu, Ofu, Omala, Mopa Muro, etc. This situation has created debilitating security challenges including high incidence of crime, policy formulation, law enforcement, criminal justice and economic problems to Kogi State and the country in general. In the light of the foregoing, an empirical study situated in a valid theoretical grasp of these conflicts is appropriately imperative.

In this regard, the understanding of some explanations of conflicts in developing countries (especially Nigeria) is insightful and necessary. However, it is also imperative to note that as long as value differences exist, crises and conflicts are normal phenomena in society (Yakubu et al, 2005). It is for this reason that several theories have been developed to explain the various conflicts plaguing the Nigerian society. One of these theories is the modernization theory which explains that the incessant conflicts in Nigeria are due to lack of modernization similar to that in advanced countries. Another is the political economy perspective which has the opinion that it is the struggles for the control of state power and poor governance by Nigerian elite that engenders ethnic, 
religious and other conflicts by ordinary citizens. The failed state explanation is of the opinion that conflicts and crises in the Nigerian society are manifestation of a failed state (Ekpekurede, 2005).

The question however is: what are the findings about the security implications of farmers/herdsmen conflicts in Kogi State suggesting about national security in Nigeria (bearing in mind these explanations)? What are the appropriate way forward, bearing in mind the findings and conclusions of this study? These are the fundamental objectives of this study.

\section{CONCEPTUAL REVIEW}

Human security, according to United Nations Development Programme (UNDP, 1994) may include such chronic threats as hunger, disease and repression. It may also be defined as the state of being safe or secure from danger, etc. Thus, security has many meanings but the concern of this work is to understand security as protection, particularly the activities involved in the protection and making safe a country, groups, communities, buildings, persons, etc (Hornby, 2010).

National security from the above perspective is the defence of a country against internal and external threat to national unity, cohesion, peace, aspirations, goals, etc. According to Anyadike (2013) national security now encompasses a broad range of activities which impinge on non-military or economic security of the nation and the values supported by the society. In this regard, national security is the requirement to maintain the survival of a country through the use of economic, diplomacy and political power. It is the cherished value associated with the physical safety of individuals, groups or nation-states together with a similar safety of their other cherished values. It denotes freedom from threats, anxiety and danger. This is ensured through security agencies (Nweke and Nwachukwu, 2014).

Conflicts refer to situations which people, groups or countries are involved in a serious disagreement. It is a violent situation or period of fighting between two countries or groups (Hornby, 2015). Conflicts exist in any human society. Its existence is not a strange phenomenon but what must be expected as long as differences abound amongst human beings (Iji, 2005; Ekpekurede, 2005). In Nigeria, for instance, conflicts have ravaged the country in varying proportion, ranging from ethnic, religious, economic as well as political crises and conflicts.

Several theories have been developed to explain the incessant conflicts in the Nigerian state. Prominent among these theories are the modernization theory, the political economy theory and the failed state theory. The modernization theory is predicated upon the assumption that most Third World countries are still crude or traditional, and with unenlightened people (a situation which propels conflicts and crises).

Modernization theory thus posits that with increasing modernization, industrialization, urbanization, free enterprise, social mobility, independent judiciary, etc, Third World countries will develop and conflicts and crises will no longer be prevalent. This theory is saying that countries like Nigeria are conflicts - ridden because they are not modernized like developed European countries. This theory has however been criticized for being eurocentric and misleading. Despite these criticisms, however, it can be used to explain some issues about conflicts in Nigeria, for instance, the lack of and inefficient basic infrastructure in Nigeria generating conflicts and crises in the system.

Political economy theory identifies class conflicts as central to the incessant crises and conflicts in post-colonial African countries. To them, because the State controls the allocation of resources in these countries, whoever controls the state, controls allocation of resources. The struggles for this control create conflicts among citizens. According to Alavi (1972), the variables of imperialism, colonialism and neo-colonialism affected the emergent states in a way that the struggle for dominance encouraged ethnicity and religious sentiments which created crises and conflicts in these countries. This made the ruling class in these countries different from those in advanced countries. 
The essential theme of the political economy theory is centrality of the state in resources allocation and acquisition of wealth which engenders antagonism and conflicts within the elite. Hence, the various conflicts in Nigeria is by-product of the elite struggle for control of the state. Some commentators however pointed out the fallacy of assuming that economic power is the reason for political power and that the struggle for political power by the elite engenders most of the conflicts in developing countries. It is however worthy to note that some conflicts in Nigeria are creation of colonialism, neo-colonialism and class struggles by the ruling class.

A failed state, from a narrow perspective, is a political entity which has lost its authority over its population and is unable to sustain a "monopoly of the legitimate use of physical force within a given territory" (Zatman, 1995). From a broader perspective, it is when the basic functions of the state are no longer performed by the government of a country. Robert Cooper (2002) corroborates this view when he describes most developing countries as "world of failed states". This is because they can no longer fulfill the criterion of having the monopoly of the legitimate use of force. In a failed or failing state according to Stohl and Smith (1999), rulers often break the agreement with the people by neglecting their fundamental rights and using state apparatus to hunt them down or using one segment of the society against the other, etc. The scenario gives credence to thriving opposition reinforced by the abundance of small arms, light weapons, violent crimes, corruption, etc, which are encouraged by the "lack of responsibility among the governing group to fulfill the state's part of the social contract" (Stohl and Smith, 1999).

According to Ekeopara (2002) and Sankore (2001), the fact that Nigeria is drifting or a failed state is not in doubt because of the existence of massive corruption, incessant power outages, poor infrastructure, lack of coherent development plans, migration to other countries by Nigerians, thriving criminality, gross insecurity, bad governance, weak institutions, culture of violence and so on. When applied to Nigeria (in general and farmers/herdsmen conflicts in particular), the thrust of this theory is that the various ethnic, religious, political and economic crises and conflicts "are manifestations of failed state syndrome" (Ekpekurede, 2005).

While the failed state theory formed the dominant conceptual approach, it was supplemented where necessary, with some appropriate insight from other theories reviewed. This is in recognition of the fact that the social world is complicated and constantly changing, to the effect that what works now may not work in the future; and what works for one society may not work for another (Young, 1997). Theories should complement each other because solutions to social problems are as dynamic as the social problems. This is the essence of triangulation in the investigation process in social sciences.

\section{MATERIALS AND METHOD}

The study was a survey carried out in seven Local Government Areas of Kogi State's three senatorial districts. Data were collected from interviews and documentary sources. Interviews were structured and in-depth (interview of key informants) drawn from members of the public, representing the conflicting groups, traditional rulers, community leaders, peasant farmers, cattle rearers, Mieti Allah officials, formal security agents and vigilante groups. The total sample population of 238 respondents were purposely selected from the quota allotted to the various category of respondents required for the study. The data collected were both quantitatively and qualitatively analyzed. The quantitative method made use of descriptive statistics, with a bench mark of 3.5 (upper limit of mean of 3.0) as the decision rule while chi-square was used to test the significance level of the responses, in order to determine causal relationships. Qualitatively, content analysis of documents and comparative analysis of interview analyses were carried out to arrive at findings and conclusions concerning the research objectives.

\section{FINDINGS AND DISCUSSIONS}

Among other causes, this study revealed that the major cause of farmers/herdsmen conflicts in Kogi State is the struggle for the control of land resources by both groups. In terms of security implications, the study revealed that the conflicts have several 
implications on the security architecture of the state, and thus national security. This is because any security challenge in one part of the country has impact on the overall security architecture of the country. In Kogi State, the farmers/herdsmen conflicts, as revealed by this study show the following security implications:

Table 1: Security implications of farmers/herders conflicts

\begin{tabular}{|l|c|c|}
\hline \multicolumn{1}{|c|}{ Security Implications } & Mean & SD \\
\hline Loss of human lives & 3.6 & .73775 \\
\hline Stresses security agents & 3.6 & .8535 \\
\hline Leads to development of militancy & 3.6 & .7632 \\
\hline Heightens tension in the state & 3.6 & .70988 \\
\hline Creates instability & 3.5 & .78344 \\
\hline Leads to infiltration of criminals from external forces & 3.6 & .73775 \\
\hline Creates ethno-religious suspicion & 3.7 & .7377 \\
\hline Leads to arms proliferation/arms running & 3.6 & .83459 \\
\hline
\end{tabular}

Source: Researchers' Field Survey, 2018

Thus, the findings of the study on security implications are:

i. Loss of human lives

ii. Stresses security agents

iii. Development of militancy

iv. Heightens tension and political instability

v. Infiltration of the state by criminals from external sources

vi. Creates ethno-religious suspicion

vii. Arms proliferation/arms running.

The loss of lives as a result of these conflicts depletes the population of the groups concerned in Kogi State and the country. The situation affects the groups in terms of loss of bread winners and family members, as well as creating psychological problems to the bereaved such as anxiety and feelings of insecurity. The death of farmers and herdsmen also creates economic or food insecurity to the state and country, in terms of the fear and intimidation to engage in farming of crops or herding of cattles created by the conflicts.

One of the effects of the farmers/herders conflicts situation is that it makes security agents ineffective and inefficient, in their job performance. It brings additional cost on security of the state in terms of security votes, manpower, etc. Psychologically, the conflicts exert mental stress on law enforcement agents. This situation aggravates human rights abuses and extortion of suspects by security agents (Amnesty International, 2008).

The development of militancy and acts of terrorism is one of the noticeable consequences of farmers/herdsmen conflicts in Kogi State. As a result of these conflicts, most communities where they occurred have developed the attitude of self-defence and readiness to violently react to any challenge thereof. This situation has led to the emergence of militia and illegal vigilante groups (without control) in affected areas and neighbouring communities (Onyegbula; 2001, Elechi, 2003; Odikanlu, 2004; Ginifer and Ismail, 2005). The result of this is the proliferation of rebellious and deviant groups of varying criminal behaviours in Kogi State, which in turn has aggravated significantly the security situation in the state.

The farmers/herdsmen conflicts, that is now a common occurrence has heightened the political tension in the state and the country, generally. The polity is so heat up that there is general apprehension on the part of the citizenry. The state and the country is more volatile and politically unstable more than ever before. The citizens are now polarized on indigenes and settlers basis, a 
situation which further aggravates political tension and instability in the country. The agonizing psychological problems both groups and innocent citizens are experiencing currently are partly caused by these conflicts.

One of the findings of this study is the infiltration of the state by criminal elements from neighbouring states and foreign lands. Media reports (Barometer, 2016; Femi, 2016) have shown that quite a number of suspects arrested in these conflicts are mercenaries from within and outside Nigeria. These mercenaries are involved in large scale criminal activities such as banditry and cattle rustling, terrorism, militancy, Boko Haram insurgency etc in Nigeria. Their activities encourage local criminals like armed robbers, kidnappers, ritualists, rapists, arsonists, terrorists, human traffickers, etc, to increase their activities in the country. All these have grave implications on national security such as increased criminality and the effects on citizens, inefficiency and ineffectiveness of security agents, increase in security expenditure, psychological and economic insecurity, etc, as long as the conflicts continue unabetted (Odekunle, 2007; Nweke et al, 2014).

Another security consequence of the conflicts is the proliferation of illegal arms and their uses in the state and the country. This situation creates culture of violence, which in turn aggravates the insecurity of lives and property (Ginifer and Ismail, 2005; Ojomah, 2014). The culture of violence is a situation whereby the use of violence to settle disagreements becomes the norm instead of the exception. If the culture of violence (encouraged by this arms proliferation), combines with the existing security situations in the country, a lawlessness and legitimacy problems will be created for the government of the day.

Since both conflicting groups and their supporters belong to different religion and ethnic groups, gross fear and suspicion of each other will be created (whether real or imagined). This will inevitably create and encourage divisive tendencies like discrimination, segregation, ethnic cleansing, stereotype, prejudice, etc., in them (along these lines). All these tendencies affect the social psychology of the people, and are inimical to the peaceful coexistence and unity of the country. This situation unequivocally affects production and distribution of goods and services (all of which are national security matters).

\section{CONCLUSIONS}

All the findings and discussions about the security implications of farmers/herdsmen conflicts in Kogi State aggravate the existing ugly security situations in the country, such as insurgency (or Boko Haram) in the North East, cattle rustling in the North West, militancy and sabotage in South-south regions as well as widespread armed robbery, kidnapping, ethnic militia and mercenary inflows, political thurggery, human trafficking, illegal arms proliferations and gun-running, economic sabotage and vandalization of facilities, massive corruption, etc., everywhere in the country. All these implications make the national security situation in the state and the country very alarming and apprehensive. Thus, the farmers/herdsmen conflicts all over the country combine with this poor security situation are indications that the country is drifting and (if not controlled) is gradually turning into a failed state.

\section{RECOMMENDATIONS}

In view of the findings, discussions and conclusion of this study, the following recommendations are suggested as way forward:

1. The Federal Government, through the instrumentality of National Assembly should enact new and definite laws on the use of land resources. This is because the existing land use Act is deficient and ineffective in curbing conflicts arising from the use of land resources.

2. The Federal Government, as a matter of necessity and urgency should tackle the issues of Boko Haram insurgency, rural banditry, militancy and ethnic militia that are found in most parts of the country. These are the sources of violence, conflicts, mercenary inflows, gun-running, etc which aggravates insecurity and lawlessness in the land. 
3. The use of the media to consolidate national unity, peace and integration among the people instead of as divisive instrument should be paramount in government objectives and directive principles (especially the media objective in chapter two of the 1999 constitution). In this regard, media policies should address security issues such as the negative use that aggravates conflicts; use of the media and the public to combat conflict challenges; media collaboration with politicians and elite to educate citizens on conflicts; use of the media in collaboration with security agents to educate the public on national security issues; ensuring that media practice delineates areas that involve national security; etc.

4. The psychological effects of these conflicts such as suspicion, apprehension, anxiety, stress, prejudice, etc can be addressed through enlightenment policies of the state and Federal Governments, using the media, schools and public enlightenment agencies (like the National Orientation Agency).

5. The politicization of the conflicts in the state and the country can be controlled or checked by government policies that prohibit the use of conflicts by politicians for political gains.

6. Youth education and empowerment, as well as increased infrastructural development and industrialization, in relation to the Nigerian political economy should be encouraged, to reduce poverty and areas of conflicts among the people. These should be addressed by Government at all levels.

7. At the state level (and as an interim solution), the Kogi State Government, after adequate consultation, should acquire and clearly demarcate grazing lands where lands are surplus for cattle grazing. This should be a temporary measure until ranches are established to restrict cattles from roaming and destroying farms.

8. As a long term solution, the Government should encourage the establishment of ranching, as the ultimate panacea to the conflicts between farmers and herdsmen in Kogi State and the country. This is because the present free or open grazing and roaming of cattles has been the major source of conflict between farmers and herdsmen.

9. The State Government should constitute committees on Alternative Dispute Resolution, (made up of farmers and herdsmen) in Local Government areas where herdsmen settle in large numbers, to handle disputes between farmers and herdsmen in the state. The committees should review strategies to build peaceful and harmonious coexistence between farmers and herdsmen as a result of the suspicious created between them.

10. Government at all levels, as a matter of necessity, should ensure the provision of adequate security to all nooks and crannies of the state to secure people's lives and property. More security personnel (police, army, civil defence, etc) should be recruited, equipped and reinvigorated by strengthening their capacity to combat security challenges in any area in the state. Security issues should not be treated on ad-hoc basis, rather the operatives should be more pro-active, efficient and effective in intelligence gathering.

\section{REFERENCES}

Alavi, H. (1972), “The State in Post-Colonial Societies: Pakistan and Bangladesh” New Left Review. 74 July - August, PP 159 183.

Amnesty International (2008), Nigeria: Waiting for the Hangman. London: Amnesty International Publications.

Anyadike, N.O. (2013), Boko Haram and National Security Challenges in Nigeria: Causes and Solutions. Journal of Economics and Sustainable Development 4(5), Retrieved from: http://www.iiste.org

BAROMETER (2006), “Herdsmen Metamorphosis.” The Nation Newspaper. Lagos $29^{\text {th }}$ May.

Cooper, R. (2002), “The Post Modern State” in Mark Leonard ed. Reordering the World. London: the Foreign Policy Centre. 
Elechi, O.O. (2003), "Extra-Judicial Killings in Nigeria. The case of Afikpo Town". Conference Paper Presented at the $17^{\text {th }}$ International Conference of the Society for the Reform of Criminal Law. The Hague. $24^{\text {th }}-28^{\text {th }}$ August.

Ekeopara, N. (2002), “Obasanjo: Three years of Motion no Movement” Houston U.S. Africa. The Newspaper, May 20.

Ekpekurede, W. (2005), "Conflicts and crises in Nigeria: A Theoretical Analysis" in Yakubu, et al, Vol. I, Kaduna NDA Press.

Femi, O. (2016), “The Looming Cattle War in Nigeria". The National Newspaper, Lagos, $29^{\text {th }}$ May.

F.R.N. (1999), The Constitution of the Federal Republic of Nigeria, Lagos: Government Press.

Ginifer, J. and Ismail, O. (2005), “Armed Violence and Poverty in Nigeria” Mini Case study for Violence and Poverty Initiative, Bradford: University of Bradford.

Hammonda, P.B. (1961), Yatenga: Technology in the culture of a West African Kingdom, Free Publications, United States.

Hornby, A.S. (2015), Advanced Learners Dictionary Oxford: Oxford University Press.

Iji, E.M. (2005), "Theoretical Perspective on Conflict" in Yakubu, A.Y. et al (eds) Crisis and Conflict in Nigeria Since 1980, Vol.I, Kaduna NDA Press (PP. 83 - 106).

Makiberidze, A. (2015), in Abraham, A.J. (2017), Patternisation and Threats of Fulani Herdsmen Attacks to Contemporary Security in Nigeria, CARD International Journal of Social Sciences and Conflict Management, Vol.2 No.2.

Nweke Prince O. \& Nwachukwu Tochukwu Stephen (2014), National Security Issues and Challenges in Nigeria: which way forward. International Journal of Youths Empowerment and Entrepreneurship Development (Vol.(1) 96 - 106).

Odekunle, F. (2004), "Overview of Policing in Nigeria: Problems and Suggestions". In E.O.E. Alemika and I.C. Chukwuma (eds) Crime and Policing in Nigeria: Challenges and Options. Lagos: CLEEN Foundations.

Odinkalu, A.C. (2004), "When did the Police become your Friend?: Changing Roles of Civil Society in Promoting Safety and Security in Nigeria". In E.O.E. Alemika and I.C. Chukwuma (eds) Crime and Policing in Nigeria: Challenges and Options. Lagos: CLEEN Foundations.

Ojomah, B.A. (2014), "Human Rights Violations in the Enforcement of Armed Robbery Laws in Kogi State, Nigeria”. Unpublished Ph.D. Thesis, Kogi State University, Anyigba.

Okiro, M. (2004), "Proliferation of Illegal Arms and Ethno-Religious Violence in Nigeria" In E.O.E. Alemika and I.C. Chukwuma (eds) Crime and Policing in Nigeria: Challenges and Options. Lagos: CLEEN Foundations.

Onyegbula, S. (2001), “The Human Righjts Situation in Nigeria since the Democratic Dispensation” Development Policy Management Network Bulletin, Vol.XII, No.3 (PP.14-16).

Rashid, S.A. (2012), Land Use Conflict between Farmers and Herdsmen: Implications for agricultural and Rural Development in Nigeria, cdn.intechopen.com.pdf

Sankore, R. (20-01), Nigeria: The Nation State and Patriotism" in Yakubu et al, eds (2005), Crisis and Conflict Management in Nigeria since 1980, Vol. I, Kaduna NDA Press.

Stohl, R. and Smith, D. (1999), "Small Arms in Failed States: A deadly Combination". U.S.A. Failed states and International Security Conference, April, 8 - 11.

UNDP (1994), Human Development Report, New York: Oxford University Press.

Yakubu, A. Y; Adegboye, R.T; Ubah, C.N. and Dogo, B. (2005) eds Crisis and Conflict Management in Nigeria since 1980. Vol. I, Causes and Dimensions of Conflicts, Kaduna NDA Press.

Young, J. (1997), "Left Realist Criminology: Radical in its Analysis, Realistic in its Policy" in M. Maguret, et al (eds). The Oxford Handbook of criminology, $2^{\text {nd }}$ ed. Oxford. Oxford University Press. 
Zartman, W. (1995), "Introduction: Posing the Problem of State Collapse" in Zartman ed. Collapse States: The Disintegration and Restoration of Legitimate Authority, London: Colorado and Lynn Reiners Publishers. 